\title{
SENSORS AND INFORMATION SYSTEM
}

\section{СЕНСОРИ ТА ІНФОРМАЦІЙНІ СИСТЕМИ}

УДК 004.722

\section{РЕКОНФІГУРАЦІЯ МУЛЬТИСЕНСОРНОЇ СИСТЕМИ ЗА УМОВИ ВПЛИВУ ДЕСТАБІЛІЗУЮЧИХ ФАКТОРІВ}

\author{
Д. П. Кучеров
}

Центральний науково-дослідний інститут озброєння та військової техніки Збройних Сил України, пр. Повітрофлотський, 28б, Київ - 49, 03049, d_kucherov@ukr.net

\section{РЕКОНФІГУРАЦІЯ МУЛЬТИСЕНСОРНОЇ СИСТЕМИ ЗА УМОВИ ВПЛИВУ ДЕСТАБІЛІЗУЮЧИХ ФАКТОРІВ}

\author{
Д. П. Кучеров
}

\begin{abstract}
Анотація. Розглядається мультисенсорна система, що складається з обмеженої кількості вимірювальних сенсорів, систем зв'язку та індикації результату вимірювання. На підставі подібності побудови мультисенсорної системи і комп'ютерних мереж подається аналіз відомих топологій передачі вимірювальної інформації на індикаторний пристрій. Маршрут передачі інформації від віддаленого сенсору до пункту контролю встановлюється за умовою мінімальності тривалості. Вимірювання в умовах природних та штучних перешкод вимагає певної реконфігурації початкової топології, адекватність якої аналізується за схемою «загибельрозмноження».
\end{abstract}

Ключові слова: мультисенсорна система, топологія, реконфігурація, схема «загибельрозмноження〉

\section{RECONFIGURATION MULTISENSORY SYSTEM IN CONDITIONS OF IMPACT OF DESTABILIZING FACTORS}

\section{P. Kucherov}

Abstract. In this paper considered the multi-sensor system that consist of a limited number of measurement sensors, communication system and system where displaying the measurement result. Based on the similarity of construction of multi-sensor system and computer network topologies is given analysis of known way transmission of measurement data to a display device. The route of 
transmission of information from a remote sensor to the control point established for a minimum length of the data transmission path. The measurements under natural and artificial obstacles requires some reconfiguration of the starting topology that adequately analyzed by a "deathreproduction" scheme.

Keywords: multisensory system, topology, reconfiguration, "death-reproduction" scheme

\title{
РЕКОНФИГУРАЦИЯ МУЛЬТИСЕНСОРНОЙ СИСТЕМЫ В УСЛОВИЯХ ВОЗДЕЙСТВИЯ ДЕСТАБИЛИЗИРУЮЩИХ ФАКТОРОВ
}

\author{
Д. П. Кучеров
}

Аннотация. Рассматривается мультисенсорная система, состоящая из ограниченного количества измерительных сенсоров, систем связи и индикации результата измерения. На основании сходства построения мультисенсорной системы и компьютерных сетей даётся анализ известных топологий передачи измерительной информации на индикаторное устройство. Маршрут передачи информации от удаленного сенсора к пункту контроля устанавливается при условии минимальной продолжительности. Измерения в условиях естественных и искусственных помех требуют определенной реконфигурации начальной топологии, адекватность которой анализируется по схеме «гибель-размножение».

Ключевые слова: мультисенсорная система, топология, реконфигурация, схема «гибельразмножение»

Останнім часом широкого застосування отримують мультисенсорні системи завдяки значним досягненням в галузі наноелектроніки, біології та за рахунок застосування нових способів оброблення інформації, що відзначається бурхливим ростом кількості публікацій в зазначеному напряму [1-10]. Їх відомими прикладами $є$ сенсорні панелі сучасних телекомунікаційних засобів, електронні аналізатори смаку та запаху, мережі безпровідних датчиків виконавчих пристроїв.

У військовій сфері мультисенсорні системи знаходять застосування при проведенні розвідки, моніторингу навколишнього середовища, діагностики стану складних вимірювальних систем. Досвід останніх локальних конфліктів свідчить, що в якості датчиків мультисенсорної розвідувальної системи застосовують безпілотні летальні апарати (наприклад, розробка БПЛА «Орлан-10» передбачає групу 4-6 апаратів, що передають інформацію один-одному і далі на пункт керування) [6-8, 10]. Їх використання стає ефективним при дослідженнях територій великого розміру або застосуванні завад. Отримання інформації про повітряну обстановку можливо від багатоканальної радіолокаційної системи, в якій кожний канал $\epsilon$ окремим сенсором [11].

За своєю суттю мультисенсорна система являє собою сукупність взаємозв'язаних датчиків невисокої ефективності. Але в разі ïx застосування підвищуються показники продуктивності системи, іiі надійність та живучість. Оброблення інформації від такої системи за певними алгоритмами може дати суттєві результати, які не можна отримати найдосконалішими звичайними приборами з одним вимірювальним сенсором. Структурно мультисенсорна система має ієрархічну чи мережеву конфігурацію, що складається з вузлів, роль яких виконують сенсори, та зв'язки між ними. Певні переваги над ієрархічною конфігурацією має мережева структура системи, перш за все в часі обміну інформації між вузлами мережі, але стає надзвичайно складною при збільшенні кількості вузлів. Створення мультисенсорних систем здійснюється на підставі досвіду, накопиченого при побудові телефонних, комп'ютерних, транспортних мереж, нафтогазової системи $[12,13]$. 
Проблемою функціонування мультисенсорної системи є частковий вихід з ладу її елементів чи втрати інформації, що може відбуватися не тільки за рахунок випадкового виходу з ладу самого сенсора, а й лінії зв'язку з ним або впливу факторів, що знижують її ефективність та потребують реконфігурації (перебудови) системи та призводить до зміни їі топології.

Метою статті $\epsilon$ аналіз функціональності систем, що складаються 3 датчиків інформації за умови впливу факторів, які знижують ïx ефективність, та визначення показників іiі реконфігурації незалежно від початкової топології.

Аналіз останніх досліджень та публікацій

Мультисенсорні системи призначені для видачі інформації про навколишнє середовище з високою точністю, що визначається побудовою та принципами оброблення інформації. Вони стаціонарні, якщо не змінюють свого координатного положення в просторі та такі, що рухаються.

В стаціонарних системах підвищення точності вимірювальної системи отримують ваговим сумуванням інформації від кожного сенсора. Цифрове оброблення інформації дозволяє вимірювати з точністю, що наближається до потенційної [11].

Організація рухомих мультисенсорних систем грунтується на принципах організації взаємодії між окремими сенсорами. Принципи динамічної децентралізованої взаємодії сенсорів, які виконують функцію активного сенсора, на основі погодженості рівнів функціонування (SLA, service level agreement) надані в [9]. Динамічна взаємодія базується на клонуванні, поділі ресурсів та адаптації зв'язку. Децентралізація не виключає центрального сенсора, який лише передає інформацію. Робота системи нагадує звичайну мережу.

Моніторинг рухомої цілі в динамічному середовищі може здійснюватися роєм безпілотних літальних апаратів (роботів), які виконують сенсорну функцію в системі, подано в [14]. Дестабілізуючим фактором для функціонування системи є порушення дистанцій та інтервалів безпілотних апаратів при русі, що створює небезпеку сусіднім апаратам. Безпека дій рухомих датчиків досягається створенням штучного притягуючого потенціального поля, яке керується контр- олером стану зворотного зв'язку. Генероване потенціальне поле фіксує відносні положення елементів системи та дозволяє безпечно відстежувати ціль. Притягуюче потенціальне полем створює умови виконання завдання іншим апаратам без зіткнень. Відштовхуюче потенційне поле в певній області створює умови для уникнення перешкоди.

Оптимізація організації групи рухомих сенсорів за допомогою теорії графів запропонована в [15]. Розроблений підхід дозволяє визначити оптимальну побудову групи рухомих сенсорів в залежності від інтенсивності обміну інформацією.

Обмін інформації між окремими сенсорами в просторі відбувається за певним маршрутом, який задається точками. Подання маршруту за геометричним підходом розглядається в [16]. 3'єднання точок різними прямими лініями та арочними кривими породжує множинність вибору маршруту. Оптимальність маршруту досягається введенням обмеження на кривизну траєкторії, яка повинна задаватися відсутністю перетину кривих рівної відстані і мінімальністю відстані між окремими точками.

Організація обміну інформації між елементами системи на основі пакетного підходу передачі інформації проаналізовано в [17]. Встановлено показники протоколів для забезпечення передачі обмеженого пакету даних.

Підходи зв'язані з виходом з ладу елементів мультисенсорної системи розглядаються в роботах $[18,19]$ на прикладі мобільних систем зв'язку. Показником ефективності таких систем висувається коефіцієнт готовності системи, що є виправданим в окремих випадках. На жаль, єдиного підходу до аналізу мультисенсорних систем з рухомими датчиками наразі не розроблено.

Метою цієї статті $€$ визначення і оцінка показників ефективності мультисенсорної системи, яка діє в умовах штучних та природних завад, що призводить до зміни конфігурації системи 3 позиції теорії систем масового обслуговування. Особливістю системи є рухомість датчиків в просторі.

\section{Постановка проблеми}

Мультисенсорну систему подаємо вимірювальною мережею 3 двонапрямленими зв'язками між іiї елементами (вузлами). Вузли 
мережі здатні приймати, перетворювати, передавати інформацію, зміна конфігурації системи можлива за умови включення додаткових чи виключення несправних датчиків. Спосіб управління мережею відповідає архітектурі «клієнт-сервер». Організація зв'язку між вузлами в мережі графічно зображується топологію мережі чи графом. В залежності від типу з'єднань вузлів розрізнюють топології: шина, кільце, зірка, коміркова та їх комбінації. Вибір топології мережі визначається факторами, серед них є віддаленість, безпечність, надійність, вартість та інші, які розглядають при розробленні системи. Розповсюджені топології побудови вимірювальної мережі на основі аналізу структури комп'ютерних мереж подаються в табл.1.

Класичні топології «шина», «кільце» та «зірка» використовуються рідше, найчастіше застосовуються гібридні топології. Їх важливість викликана потребами суспільства та розвитком обладнання для створення локальних мереж. Ці топології мають кращі показники надійності та масштабованості, але потребують розподілу трафіку та, відповідно, додаткового обладнання. Для мереж з обміном великими потоками даних (цифрові зображення, завантаження файлів, додаткові засоби безпеки) пропускна здатність мережі значно знижується.

Кількість сенсорів в мультисенсорній системі зазвичай більше трьох, взаємодія здійснюється шляхом обміну повідомленнями. Формальний опис мультисенсорної системи повинен включати перелік сенсорів $C_{i}$, peзультати вимірювань $W$, набір повідомлень $M_{k}$, спосіб видачі інформації (синхронний чи асинхронний). Наприклад,

$$
\left(C_{i}: i=5 ; W_{j}: j=1 . . n ; M_{k}: k=1 . . m ; \text { Async }\right) .
$$

Запис (1) означає, що мультисенсорна система складається 35 сенсорів, що вимірює 3 дискретністю $n$, видача інформації здійснюється за запитом (асинхронна).

Ставиться завдання визначити можливості ефективного вимірювання системи, що має $i$

Типи топологій

\begin{tabular}{|c|c|c|c|c|}
\hline Мережа & Розгортання & Надійність & $\begin{array}{l}\text { Доставка } \\
\text { пакетів }\end{array}$ & Схема доступу \\
\hline Ш & $\begin{array}{l}\text { Просте, шляхом } \\
\text { підключення до } \\
\text { загальної шини, але } \\
\text { не більше } 10 \text { вузлів }\end{array}$ & $\begin{array}{l}\text { Дефекти в } \\
\text { кабельній } \\
\text { магістралі } \\
\text { виводять } 3 \text { ладу } \\
\text { всю мережу }\end{array}$ & $\begin{array}{l}\text { До кожного } \\
\text { комп’ютера } \\
\text { мережі пакети } \\
\text { поступають } \\
\text { одночасно } \\
\end{array}$ & Конкурентна \\
\hline & $\begin{array}{l}\text { Мінімум } \\
\text { апаратного } \\
\text { забезпечення, } \\
\text { просте } \\
\text { настроювання та } \\
\text { розгортання } \\
\end{array}$ & $\begin{array}{l}\text { Відмова вузла } \\
\text { приводить до } \\
\text { відмови мережі }\end{array}$ & $\begin{array}{l}\text { Рівні можливості } \\
\text { щодо отримання } \\
\text { пакетів }\end{array}$ & $\begin{array}{l}\text { Маркерна } \\
\text { («token») }\end{array}$ \\
\hline & $\begin{array}{l}\text { Простота } \\
\text { масштабування, } \\
\text { необхідність } \\
\text { концентратора }\end{array}$ & $\begin{array}{l}\text { Критичний } \\
\text { елемент } \\
\text { концентратор }\end{array}$ & $\begin{array}{l}\text { Одне посилання } \\
\text { тільки одному } \\
\text { комп'ютеру, } \\
\text { можливі } \\
\text { затримки }\end{array}$ & Адресна \\
\hline Коміркова & $\begin{array}{l}\text { Необхідність } \\
\text { забезпечення } \\
\text { взаємодії з } \\
\text { сусідніми вузлами }\end{array}$ & $\begin{array}{l}\text { Втрата однієї } \\
\text { лінії зв'язку не } \\
\text { впливає на } \\
\text { роботу мережі }\end{array}$ & $\begin{array}{l}\text { Пакети } \\
\text { поступають } \\
\text { адресно }\end{array}$ & Адресна \\
\hline
\end{tabular}




\begin{tabular}{|l|l|l|l|l|}
\hline $\begin{array}{l}\text { Шина- } \\
\text { зірка }\end{array}$ & $\begin{array}{l}\text { Потребує } \\
\text { додаткового } \\
\text { обладнання }\end{array}$ & $\begin{array}{l}\text { Втрати } \\
\text { працездатності } \\
\text { фрагменту не } \\
\text { впливає на всю } \\
\text { мережу }\end{array}$ & $\begin{array}{l}\text { Проблеми } \\
\text { розподілу } \\
\text { трафіку }\end{array}$ & $\begin{array}{l}\text { Конкурентність } \\
\text { по шині, } \\
\text { адресність по } \\
\text { зіркі }\end{array}$ \\
\hline $\begin{array}{l}\text { Зірка на } \\
\text { кільці }\end{array}$ & $\begin{array}{l}\text { Необхідність } \\
\text { додаткового } \\
\text { обладнання } \\
\text { оонцентратора, } \\
\text { що керує кільцем }\end{array}$ & $\begin{array}{l}\text { Проблеми } \\
\text { розподілу } \\
\text { трафіку }\end{array}$ & $\begin{array}{l}\text { Рівний доступ } \\
\text { за рахунок } \\
\text { маркерів }\end{array}$ \\
\hline $\begin{array}{l}\text { Пібридна } \\
\text { Коміркова }\end{array}$ & $\begin{array}{l}\text { додребує } \\
\text { обладнового }\end{array}$ & $\begin{array}{l}\text { Менша } \\
\text { надійність ніж } \\
\text { чисто коміркової }\end{array}$ & $\begin{array}{l}\text { Проблеми } \\
\text { розподілу } \\
\text { трафіку }\end{array}$ & $\begin{array}{l}\text { Необхідність } \\
\text { адресації }\end{array}$ \\
\hline
\end{tabular}

сенсорів, в умовах впливу природних чи штучних перешкод на систему (1).

\section{Обмін інформацісю}

Передача інформації в мультисенсорній системі відбувається згідно з правилами, що називають протоколами. Ними встановлюється адреса користувача, їх кількість і швидкість передачі даних. Адреса користувача може бути індивідуальною чи груповою, коли інформація розсилається групі або деякій підгрупі користувачів. Такий спосіб адресації подібний до адресації в комп'ютерних мережах, коли передача даних відбувається від адреси джерела до адреси приймача.

Якщо група сенсорів велика, то виникає ситуація, коли інформація передається через транзитні вузли. Але при цьому стає необхідність забезпечення прокладання маршруту 3 мінімумом часу на доставку інформації, що досягається найменшою кількістю транзитних вузлів або наявністю каналів з високою пропускною здатністю чи надійними лініями зв'язку. При цьому збільшення кількості транзитних вузлів з великою пропускною здатністю $є$ переважним над мінімальною кількістю вузлів 3 невеликою пропускною здатністю за часом передачі інформації.

Через вузол може проходити декілька підпотоків, їх відрізняють за адресом пункту призначення. Зрозуміло, щоб визначити маршрут, який би забезпечив рівний час потоків різного обсягу даних, необхідно враховувати швидкість передачі, яку мають окремі лінії, та на- давати можливість проведення відокремлювання підпотоків та їх збірку. Переключення вузлів для передачі підпотоків здійснюється за рахунок мультиплексування вільних транзитних вузлів.

\section{Задача маршрутизації}

За цією задачею визначається маршрут проходження інформації кінцевому користувачу. Якщо маршрут статичний, то він задається одноразово або за певним розкладом та не змінюється в межах певного часу дії вимірювальної системи. Динамічні маршрути обчислюються відповідними алгоритмами в залежності від топології та стану вимірювальної мережі. До них відносяться алгоритми пошуку найкоротшої відстані в ширину, Дейкстри, БеллманаФорда, Флойда-Воршалла [20, 21].

Пошук в ширину. Нехай заданий граф $G=(W, E)$, в якому визначені стартова $s$ і кінцева $k$ вершини. Проводиться обхід кожної вершини $w_{j} \in W$ графа $G$, запам'ятовується кількість прсєе дених ребр (дуг) $e_{i} \in E, i=1 . . N$, $j=1 . . M$. Мінімальна відстань $L(s, i \in$ між точками $s$ та $k$ відповідає найменшій кількості ребр, що з'єднують вершини $s$ i $k$

$$
L(s, k)=\min _{e \in E} \sum_{i=1}^{N} e_{i},
$$

де $N$ - кількість дуг у графі. Приклад застосування алгоритму наведений на рис. 1. 


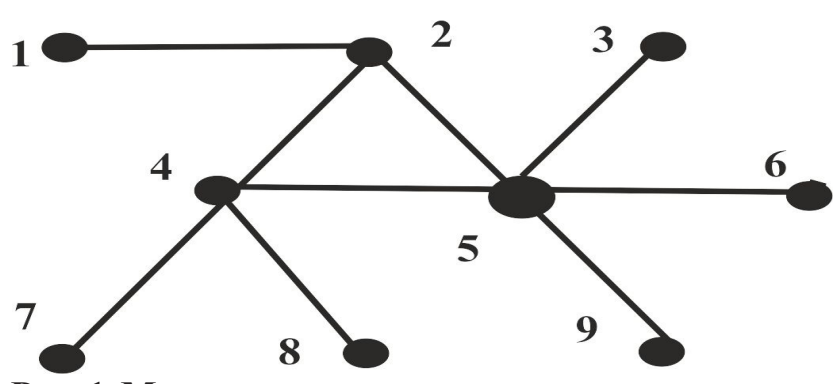

Рис. 1. Мультисенсорна система, що складається 39 сенсорів.

Найкоротший маршрут передачі інформації між вершинами 1-9 за алгоритмом (2) відповідно до рис. 1 складає $L(1,9)=3$.

Оцінкою продуктивності графа виступає часова складність $O(\cdot)$, що визначається кількістю операцій за алгоритмом (2). За цим алгоритмом усі вузли та ребра скануються одноразово, тому часова складність визначається їх кількістю, а саме $O(M+N)$.

Алгоритм Дейкстри $\epsilon$ процедурою пошуку найкоротшого шляху на зваженому орієнтованому графі. Алгоритм використовується протоколами маршрутизації OSPF та IS-IS в IP-мережах $[12,21]$. Відповідно до цього алгоритму будується орієнтоване дерево $з$ наявних вершин $y \leq N$ графа, починаючи 3 вершини $s=1$, де $N$ - загальна кількість вершин, будується дерево $D$. Ребра графа мають вагу $\omega(i, j)$ таку, що

$$
\omega(i, j)=\left\{\begin{array}{l}
0, \text { якщо } i=j, \\
\omega>0, \text { якщо }|i-j|=1, \\
\infty, \text { якщо інакше. }
\end{array}\right.
$$

Довжина шляху на кожному кроці $k$ від вершини $s$ визначається правилом

$$
\begin{aligned}
& L(k)=\min _{y}[L(k), L(y)+\omega(y, k)] \\
& \text { для } y \notin D, L(s)=0 .
\end{aligned}
$$

Правило (4) не дозволяє робити проходи по гілкам дерева $D$ з великою вагою. Таким чином, множина вершин в створюваному дереві шляхів $D$ являє собою впорядковану послідовність зв'язаних між собою вузлів, яка містить найкоротший шлях від вершини $x$ до $k$. Цей шлях показаний на рис. 2 стрілками.

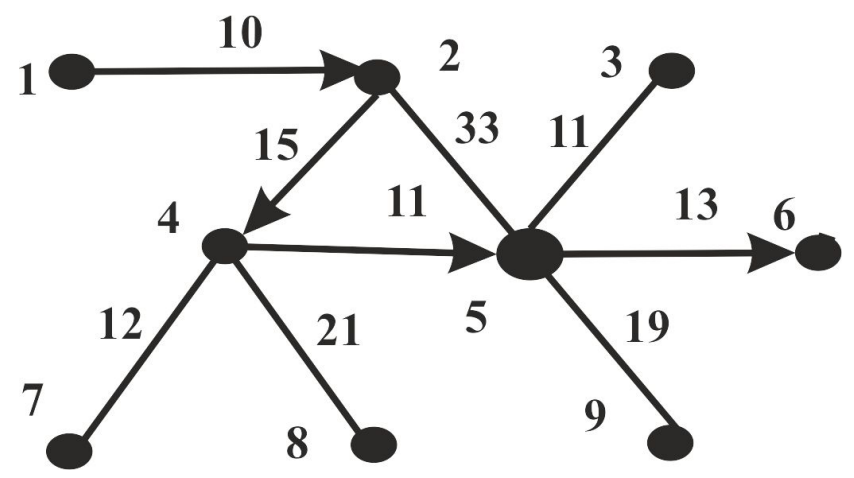

Рис. 2. Передача інформації в мультисенсорній системі зі зваженою структурою графа.

Оскільки алгоритм є ітераційним, то число ітерацій визначається кількістю вершин графа, тому часова складність алгоритму $O(N)$. В межах кожної ітерації, відбувається нове проходження 3 врахуванням нової $(y+1)$ вершини. При цьому вершини з найбільшою вагою вивільняються, а довжина шляху 3 новими вершинами поновлюється, кращий результат запам'ятовується. Це те ж оцінюється кількістю вершин. Загальна продуктивність алгоритму оцінюється величиною $O\left(N^{2}\right)$. Таким чином, алгоритм Дейкстри $є$ ресурсоємним, але завдяки знанням топології мережі і шляху до потрібної вершини, маршрутизатор завжди знаходить альтернативний шлях до потрібного вузла мережі у випадку виникнення проблем у будь-якому вузлу визначеного шляху.

Алгоритм Беллмана-Форда. За суттю цей алгоритм нагадує попередній (Дейкстри). На відміну від алгоритму Дейкстри цей алгоритм не відкидає ребр з великою вагою та ітераційно розраховує довжину усі шляхи в графі, запам'ятовуючи мінімальний шлях. Кількість ітерацій, як і алгоритмі Дейкстри визначається кількістю вершин, а кількість розрахунків в межах ітерації кількістю ребр, то часова складність алгоритму оцінюється величиною $O(V \cdot E)$. Результат цього алгоритму для графа рис. 2 співпадає 3 алгоритмом Дейкстри. При однакових розмірах графа алгоритм Дейкстри $\epsilon$ менш ресурсоємним ніж Беллмана-Форда, а значить більш швидкий. Зменшення ресурсоємності можна досягти зменшенням кількості ребр, тобто переходом до розрідженого графу.

Алгоритм Флойда-Варшалла. Основою цього алгоритму $є$ метод динамічного програмування, відповідно до якого ділянка най- 
коротшого шляху є теж найкоротшим шляхом. Таким чином, якщо знайдені усі проміжні ділянки (вузлові точки) найкоротшого шляху, то можна говорити, що й найкоротший шлях знайдений.

Нехай відома матриця ваг графа $w_{i j}$, тоді найкоротший шлях 3 вершини $i$ у вершину $j$ знаходиться за процедурою

$$
l_{i j}^{k}=\left\{\begin{array}{l}
w_{i j}, \text { якщо } k=0, \\
\min _{k}\left(l_{i j}^{k-1}, l_{i k}^{k-1}+l_{k j}^{k-1}\right), \text { якщо } k \geq 1,
\end{array}\right.
$$

де $k \quad\{1,2, \ldots, k\}-$ множина проміжних точок чрафа. Складена таким чином матриця $L$ розміру $n \times n$ дає відповіді про всі пари $i, j \quad V$. Оптимальний шлях для графу рис. 2 покњаний в матриці 9×9 сірим кольором, табл. 2 .

Таблиця 2 Матриця пошуку за алгоритмом Флойда-

\section{Варшалла}

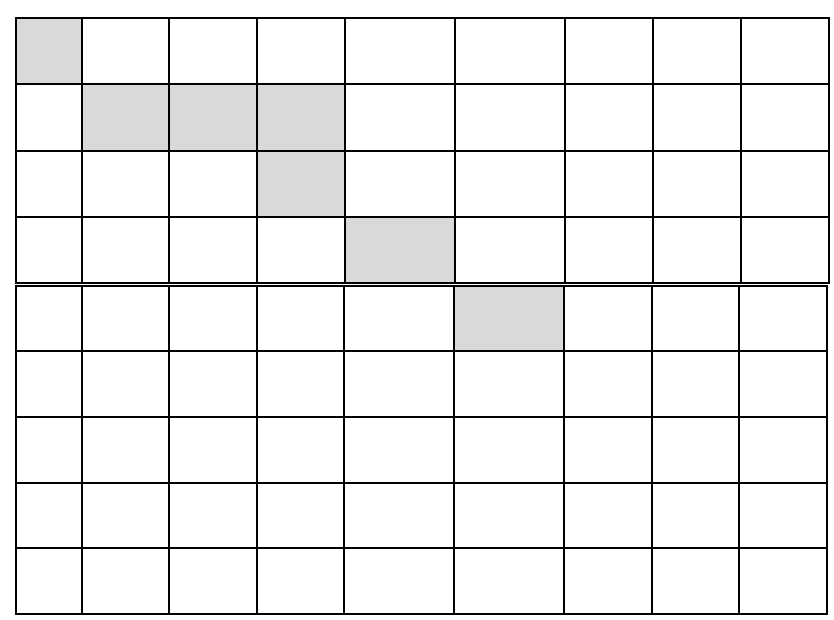

Цей алгоритм матричного типу, включає додатковий пошук $k$ проміжних вершин, тому обчислювальна складність не перевищує $O\left(n^{3}\right)$. Доцільність застосування алгоритму визначається необхідністю виявлення найкоротшого шляху між всіма парами вершин графу.

\section{Зміна структури системи}

Основною властивістю мультисенсорної системи $є$ те, що вона в процесі виконання завдань може змінювати свою структуру через дії зовнішніх факторів. Унаслідок цього зменшується розмір системи. Розмір може відновлюватися та навіть збільшуватися за рахунок підключення до системи нових елементів.
Тобто розмір системи є ії показником. Реакцією на зовнішні події є зміна топології системи, наприклад кільце стати шиною або зіркою при визначенні транзитного вузла.

Під реконфігурацією мультисенсорної системи будемо розуміти зміну будови системи, яка стосується розміру чи ії топології. Особливістю реконфігурації є перебудова структури та топології системи з метою виключення збоїв в роботі системи. Приклад реконфігурованої системи показаний на рис.3.

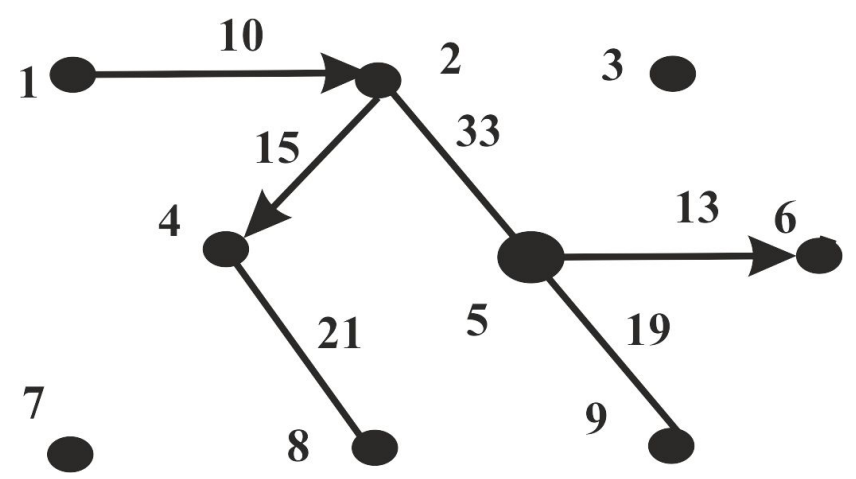

Рис. 3. Зміна будови мультисенсорної системи в разі виходу з ладу сенсорів 7 та 3.

Для оцінки ефективності системи вводяться коефіцієнти розміру системи $K_{\Sigma}$, точність вимірювання $\delta$ та швидкість реконфігурації $v_{\text {рек. }}$.

Коефіцієнтом розміру системи $K_{\Sigma}$ будемо називати відношення діючої кількості елементів системи $K_{\partial}$ до її початкової кількості $K_{\text {поч }}$

$$
K_{\Sigma}=\frac{K_{\partial}}{K_{\text {nоч }}} .
$$

3 урахуванням попередніх зауважень щодо роботи системи з (6) випливає, що $K_{\Sigma} \geq 0$. В нормальному режимі функціонування системи цей коефіцієнт дорівнює 1 , якщо $K_{\Sigma}=0$, то система не працює, за умови реконфігурації він приймає значення $K_{\Sigma} \in[0,1]$, якщо $K_{\Sigma}>1$, то відбувається нарощування системи.

Швидкість реконфігурації $v_{\text {рек }}$ повинна перевищувати швидкість виявлення збоїв в системі, тобто

$$
v_{\text {peк }} \geq(2 . .5) N_{3 \sigma} / \Delta t
$$

де $N_{\text {зб }}$ - кількість збійних вузлів за інтервал $\Delta t$. 


\section{Аналіз реконфігурації мультисенсорної системи}

Відповідно до загального уявлення про мультисенсорну систему (1) вона $є$ системою 3 обмеженою кількістю можливих станів. Тому iii поводження можна моделювати за допомогою математичного апарату аналізу марківських ланцюгів.

Будемо вважати, що в процесі роботи мультисенсорна система, яка складається 3 кінцевої множини елементів $N$, передає інформацією користувачам за алгоритмом Дейкстри, що відповідає умовам нормального функціонування системи. Цей стан є початковим, який позначимо $S_{1}$. Якщо за якимись не випадковими причинами починають виходити 3 ладу елементи системи чи пропадає передача даних, то відбувається перехід системи до іншого стану. Елементи системи не виходять 3 ладу одночасно, а по одному, тому вважається, що здійснюються послідовні переходи зі стану $S_{1}$ у стани $S_{2}, S_{3}, \ldots, S_{i}$ через певні інтервали часу $\Delta t, i$ означає номер стану. Послідовний набір станів мультисенсорної системи та переходів між ними утворює ланцюг Маркова. Оскільки ланцюг послідовний, то функціонування системи можна подати у вигляді схеми «загибельрозмноження» [23].

Нехай мультисенсорна система складається $3 n$ сенсорів, тому відповідно до підходу за схемою «загибель-розмноження» введемо стани $S_{i}, i=1 . . n+1$, де $S_{1}-$ стан системи, що відповідає функціонуванню всіх сенсорів без відмов. За умови впливу зовнішніх і внутрішніх факторів 3 фіксованою інтенсивністю $\lambda$ здійснюється перехід в стани, коли сенсори відмовляють послідовно один за другим. Таким чином, здійснюється перехід в стан $S_{2}$, коли не працює 1 сенсор, та так далі, а відповідно $S_{n+1}$ - мультисенсорна система перестала виконувати завдання у зв'язку з виходом 3 ладу всіх сенсорів. Система також може вживати заходи щодо відновлення свого функціонування, це відбувається з інтенсивністю $\mu>\lambda$. При цьому 3 інтенсивністю $\mu$ відбуваються послідовні переходи зі станів $S_{i}$ у стани $S_{i-1}$. Знайдемо ймовірності $p_{i}$ знаходження мультисенсорної системи в кожному з кінцевих станів $S_{i}$ та проаналізуємо їх. Ймовірності знаходження системи у фінальних станах знаходяться за формулами [23] $p_{i}=p_{0} \prod_{k=1}^{i}\left(\frac{\lambda}{\mu}\right)^{k}, i \neq 0, p_{0}=\left(1+\sum_{i=1}^{n} \prod_{k=1}^{i}\left(\frac{\lambda}{\mu}\right)^{k}\right)^{-1}$

Розглянемо цю задачу для випадку $n=5$, $\lambda=0,5, \mu_{1}=0,8, \mu_{2}=1,6, \mu_{3}=2,4$. Результати розрахунку за формулами (8) наведені в табл. 3.

Таблиця 3.

\section{Ймовірності станів мультисенсорної} системи в умовах реконфігурації

\begin{tabular}{|c|c|c|c|c|c|c|}
\hline$\mu$ & $p_{0}$ & $p_{1}$ & $p_{2}$ & $p_{3}$ & $p_{4}$ & $p_{5}$ \\
\hline 0,8 & 0,4 & 0,25 & 0,1564 & 0,098 & 0,061 & 0,037 \\
\hline 1,6 & 0,69 & 0,22 & 0,07 & 0,02 & 0,01 & 0 \\
\hline 2,4 & 0,79 & 0,17 & 0,03 & 0,01 & 0 & 0 \\
\hline
\end{tabular}

Деградація станів мультисенсорної системи під впливом перешкоджуючих факторів показана на рис.4. Аналіз рисунку показує, що чим більше $\mu$, тим точніше вимірювання, більше ймовірність знаходження системи у працездатному стані та менше ймовірність знаходження у непрацездатному стані.

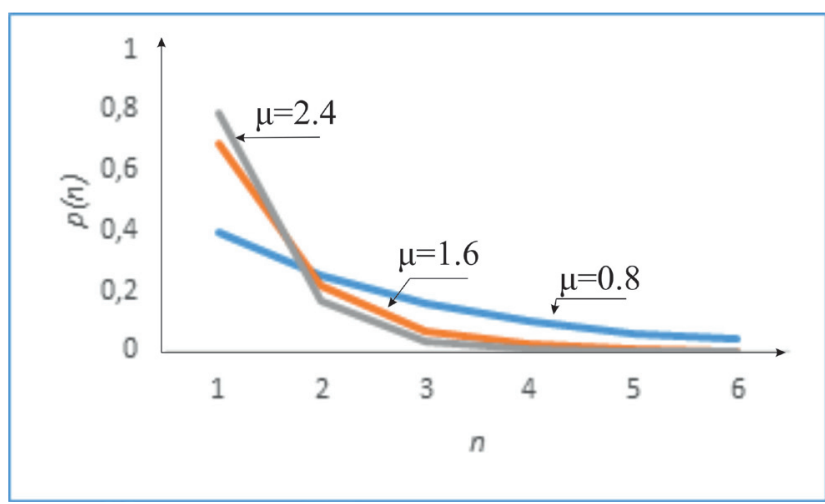

Рис. 4. Деградація мультисенсорної системи в умовах завад.

Всяке пошкодження системи впливає на їі розмір, він зменшується, але при відновленні конфігурації цей показник здатний становитися рівним початковому значенню. Мінімальне значення $K_{\Sigma}=0,2$ відповідає одному працюючому сенсору.

Швидкість реконфігурації оцінювалась за показниками інтенсивності відмов $\lambda$ та відновлення сенсорів $\mu$. Як видно з рисунку, якщо $\mu>(2 . .5) \lambda$, система $є$ більш стійкою до перешкод різних типів. 


\section{Висновки}

Мультисенсорні системи рухомого типу являють собою новий науковий напрямок організації побудови вимірювальних систем. У військовій сфері спостерігається застосування рухомих датчиків, що підтверджується практикою вирішення завдань моніторингу і розвідки повітряної обстановки, груповим виконанням бойових операцій.

Застосування мультисенсорних систем не можливе без вивчення проблемних питань, головним серед яких є отримання інформації від окремих сенсорів. Цей процес грунтується на топології, відповідно за якою встановлюється адресний обмін інформацією за мінімальним маршрутом. Топологія мультисенсорної системи військового призначення не є сталою, а піддається реконфігурації при дії в умовах дії реальних перешкод. Аналіз функціонування системи зручно зробити за відомою схемою «загибель-розмноження» сенсорів та встановлення відповідних ii показників, до яких можна віднести відносний розмір системи, точність системи та швидкість реконфігурації у сталому режимі роботи чи для певного моменту функціонування системи. Швидкість реконфігурації системи в статті асоційовано 3 інтенсивністю відмов та відновленням сенсорів. В розрахунках за схемою «загибельрозмноження» показано, що реконфігурація ефективна, якщо вона відбувається зі швидкістю більшою за інтенсивність виводу сенсорів з ладу приблизно у $2 . .5$ разів.

Подальші дослідження реконфігурації мультисенсорних систем планується зосередити на аналізі їх динамічних властивостей.

\section{Список використаної літератури}

[1]. V. P. Kоzhemјако. Optikoelectronna multisensorna Sistema ta matematichna model odinichnogo sensoru dlja vimiruvannja tovshchini rogivki oka / V. P. Kozhemjako, O. O. Shtelmah, N. V. Malachkova, S. O. Shtelmah // Optiko-elektronni vimiruvalno-energetichni tehnologii. - Vol. 28. No. 2. - 2014. - pp. 110-119 (in Ukrainian).

[2]. V. O. Romanov. Bezprovidna sensorna merezha dlja precezijnogo zemlerobstva ta ekologichnogo monitoringu / V. O. Romanov, O. V. Palagin, I. B. Galeluka, O. V. Vo- ronenko // Komputerni zasobi, merezhi ta sistemi. - No. 13. - 2014. - pp. 53-62 (in Ukrainian).

[3]. U. G. Vlasov. Multisensorni sistemi tipa elecronnij jazik - novie vozmozhnosti sozdanija i priminenia himicheskih sensorov / U. G. Vlasov, A. V. Legin, A. M. Rudnisckaja // Успехи химии. - No. 75(2). - 2006. - pp. 141-150 (in Ukrainian).

[4]. S. S. Alhasov. Structura bloka obrabotki dannih multisensornoj sistemi dlja monitiringa koncentracij ionov tyazhelih metallov $\mathrm{v}$ vodnih sredah / S. S. Alhasov, L. P. Mileshko, O. V. Pyatilova // Electronnij zhurnal nauchnij zhurnal "Inzhenernij vestnik Dona". - No. 3, 4. - 2012. - [Electronnij resurs] - rezhim dostupu: http://ivdon. ru/ $\mathrm{ru} /$ magazine/archive/n4p2y2012/1343.

Data dostupu: 12. 05. 16 (in Russian).

[5]. D. M. Bikmeev. Voltamperometricheskij «electronnij jazik»s protochnim trubchtim electrodom dlja identificacii spirtosoderzhchih rastvorov / D. M. Bikmeev, A. V. Sidelnikov, F. H. Kudasheva, V. N. Majstrenko // Analitika i control. - T. 18. - № 2. - 2014. - S. 197-203. - [Electronnij resurs] rezhim dostupu: http://aik-journal. urfu. ru/ periodical/2014/AiK-2014-18-197. pdf. Data dostupu: 12. 05. 16 (in Russian).

[6]. A. V. Karpenko. Complex «LEER» with Unmanned Aerial Vehicle «ORLAN-10». - [Electronnij resurs] - rezhim dostupu: http:// bastion-opk. ru / orlan-10/.

[7]. W. Y. J. Chou. Multi-Agent coordination and optimisation in the robocup rescue project // 18-th World IMACS. International Congress on Modelling and Simulation, MODSIM09. Modelling and Simulation Society of Australia and New Zealand, Cairns, Australia, 13-17 July 2009. pp. 1608-1614. - [Electronnij resurs] rezhim dostupu: http://mssanz. org. au/ modsim09.

[8]. L. Marsh. Multi-agent UAV path planning / L. Marsh, G. Calbert, J. Tu, D. Gossink and $\mathrm{H}$. Kwok // International Congress on Modelling and Simulation, MODSIM05. Modelling and Simulation Society of Australia and New Zealand, December 2005. - pp. 2188-2194. - [Electronnij resurs] 
- rezhim dostupu: http://www. mssanz. org. au/modsim05/papers/marsh. pdf.

[9]. D. K. Jesintha. Dynamic analysis of agent network in self organization using service level agreement technique / D. K. Jesintha, J. P. Anandh, M. Ramnath // International Journal of Engineering Science Invention. - Vol. 4. - № 3. - 2015. - pp. 44-49.

[10]. A. N. Kozub. Vimiruvalne zabezpechennja grupovogo poletu BPLA / D. P. Kucherov, A. N. Kozub, B. P. Ivanov // Perspektivi rozvitku avtomatizovanih system upravlinnja vijskami ta geovimiruvalnih system: Zb. mater. NPK 29. 01. 15 p. - Lviv: ASV, 2015. - pp. 249-251 (in Ukrainian).

[11].S. Z. Kuzmin. Cifrovaja radiolokacija / S. Z. Kuzmin. - K. : KViC, 2000. - 428 p. (in Russian).

[12]. V. Stollings. Sovremennie komputernie seti / V. Stollings. - SPb. : Piter, 2003. - 783 p. (in russian).

[13].V. G. Olifer. Komputernie seti: prinsipi, tehnologii, protokoli / V. G. Olifer, N. A. Olifer. - SPb. : Piter, 2006. - 958 p. (in Russian).

[14]. A. Dang. Formation control of leaderfollowing UAVS to track a moving target in a dynamic environment / A. Dang, J. Horn // Journal of Automation and Control Engineering. - Vol. 3. - No - 1. - 2015. pp. 1-8.

[15]. M. Shanmugavel. Differential Geometric Path Planning of Multiple UAVs / M. Shanmugavel, A. Tsourdos, B. A. White, R. Zbikowski // Transactions of the ASME. Journal of dynamic systems, measurement, and control. Vol. 129. - SEPTEMBER. 2007. - pp. 620-632.

[16].D. I. Bondarev. Modeli grupovih poletiv bezpilotnih litalnih aparativ $\mathrm{z}$ vikoristanniam teorii grafiv / D. I. Bondarev, D. P. Kucherov, T. F. Shmeleva // Nauka I tehni- ka Povitrjanih Sil Ukraine. - No. 3 (20). 2015. - pp. 68-74. (in Ukrainian)

[17].D. P. Kucherov. Control System Objects with Multiple Stream of Information / D. P. Kucherov, A. N. Kozub // Proceedings 2015 IEEE $3^{\text {rd }}$ International Conference "Actual Problems of Unmanned Aerial Vehicles Developments (APUAVD)", October 1315, 2015. - pp. 290-293.

[18]. I. E. Gorbunov. Metodologia analiza i sinteza rekonfiguriruemih topologij mobilnih setej svjazi / I. E. Gorbunov // Matematichni mashini I sistemi. - No. 2. - 2006. pp. 48-59. (in Russian).

[19]. M. M. Lastovchenko. Metod analiza effektivnosti reconfiguracii topologii besprovodnih multiservernih setej povishennoj pomehozashchishchennosti / M. M. Lastovchenko, E. E. Zubareva, V. O. Sachenko // USiM. - No6. - 2009. - pp. 79-86. (in Russian).

[20]. T. Kormen. Algoritmi. Postroenie i analiz / T. Kormen, Ch. Lejzerson, R. Rivest, K. Shtajn. - M. : ID «Viljams», 2005. 1296 p. (in Russian).

[21]. N. A. Kuznecov. Algoritm Dejkstri s uluchshennoj robastnostju dlia upravlenia marshrutizaciej v IP-setiah / N. A. Kuznecov, V. N. Fetisov // Automatika i telemehanika. - No. 8. - 2008. - pp. 80-85. (in Russian)

[22]. B. Fortz Optimizing OSPF / IS-IS weights in a changing world / B. Fortz, M. Throup // IEEE Journal on selected areas in communications, June, 2002. - P. 1-31. [Electronnij resurs] - rezhim dostupu: DOI: 10. 1109/JSAC. 2002. 1003042

[23]. E. S. Ventcel. Issledovanie operacij: zadachi, principi, metodologia / E. S. Ventcel. - M. : Nauka, 1988. - 208 p. (in Russian)

Стаття надійшла до редакції 08.06.2016 p. 
УДК 004.722

\title{
RECONFIGURATION MULTISENSORY SYSTEM IN CONDITIONS OF IMPACT OF DESTABILIZING FACTORS
}

\author{
D. P. Kucherov \\ Central Research Institute of Armament of the Armed Forces of Ukraine, \\ Povitroflotskyi av., 286, Київ-49, 03049,d kucherov@ukr.net
}

\begin{abstract}
Summary
In this paper considered the multisensory system that consist of a limited number of measurement sensors, communication system and system where displaying the measurement result. Based on the similarity of construction of multisensory system and computer network topologies is given analysis of known way transmission of measurement data to a display device.

It is noted that the network structure have a priority above hierarchical structure for the passing information in time although it structure will being extremely complex if the number of nodes are big. When building a network multisensory systems can be useful experience of building a phone networks, computer networks, transportation networks, oil and gas system, whose analysis operation conducted by graph theory and Markov chain type. If the number of sensors is significant, there is a need to transfer information via transit nodes. In this case needs to provide recognition signal measurement in transmitted information. This achieved using algorithms of recognition and identification. Junction construction creates a subflow of information and requires a connection node by its multiplexing.

The transmission of information from a remote sensor to the control point established for a minimum length of the data transmission path. The general idea of the multisensory system states that it is a system with a limited number of possible states, so its behavior can be modelled using mathematical apparatus of Markov processes. The measurements under natural and artificial obstacles requires some reconfiguration of the starting topology that adequately analyzed by a "death-reproduction" scheme.

Keywords: multisensory system, topology, reconfiguration, "death-reproduction" scheme
\end{abstract}


УДК 004.722

\title{
РЕКОНФІГУРАЦІЯ МУЛЬТИСЕНСОРНОЇ СИСТЕМИ ЗА УМОВИ ВПЛИВУ ДЕСТАБІЛІЗУЮЧИХ ФАКТОРІВ
}

\author{
Д. П. Кучеров \\ Центральний науково-дослідний інститут озброєння та військової техніки Збройних Сил \\ України
}

\section{Реферат}

Розглядається мультисенсорна система, що складається з обмеженої кількості вимірювальних сенсорів, систем зв'язку та індикації результату вимірювання. На підставі подібності побудови мультисенсорної системи і комп’ютерних мереж подається аналіз відомих топологій передачі вимірювальної інформації на індикаторний пристрій.

Відзначається, що мережева структура системи має перевагу над ієрархічною за часом проходження інформації, але є надзвичайно складною при збільшенні кількості вузлів. При побудові мережевих мультисенсорних систем може бути корисним досвід побудови телефонних, комп'ютерних, транспортних мереж, нафтогазової системи, при аналізу функціонування може бути застосована теорії графів та ланцюгів марківського типу. Якщо кількість сенсорів значна, то виникає необхідність передавати інформацію через транзитні вузли. При цьому стає необхідно забезпечувати розпізнавання сигналів вимірювання в інформації, що передається. Це досягається застосуванням алгоритмів розпізнавання та ідентифікації. Вузлова побудова утворює підпотоки інформації та вимагає переключення вузлів шляхом ії мультиплексування.

Інформація від віддаленого сенсору передається до пункту контролю за умовою мінімальності довжини маршруту передачі інформації. Відповідно до загального уявлення про мультисенсорну систему стверджується, що вона є системою з обмеженою кількістю можливих станів, тому іiі поведінку можна моделювати за допомогою математичного апарату марківських процесів. Вимірювання в умовах природних та штучних перешкод вимагає певної реконфігурації початкової топології, адекватність якої аналізується за схемою «загибель-розмноження». Оскільки вихід з ладу окремих сенсорів відбувається за умови дій зовнішніх впливів, то для аналізу реконфігурації системи пропонується аналіз функціонування мультисенсорної системи ланцюгами Маркова.

Ключові слова: мультисенсорна система, топологія, реконфігурація, схема «загибель-розмноження〉 